\title{
REGULATION BY ISOPROTERENOL OF MUSCARINIC ACETYLCHOLINE RECEPTOR NUMBERS AND SENSITIVITY IN RAT SUBMANDIBULAR, BUT NOT LACRIMAL, GLANDS
}

\author{
SETH R. HOOTMAN \\ Department of Anatomy and Cell Biology, The University of Michigan, Medical Sciences II, Ann Arbor, MI 48109 (U.S.A.)
}

(Received December 21st, 1981)

Key words: Isoproterenol regulation; Acetylcholine receptor; Receptor sensitivity, (Rat salivary gland)

Chronic administration of DL-isoproterenol, a $\boldsymbol{\beta}$-adrenergic agonist, to male Sprague-Dawley rats increased submandibular gland weights by 3 to 4 -fold. This increase resulted from a combination of hyperplasia and hypertrophy of secretory cells. Possible effects of this drug regimen on submandibular gland muscarinic acetylcholine receptors were examined by analysis of the binding of the cholinergic antagonist, L-quinuclidinyl $\left[{ }^{3} \mathbf{H}\right]$ benzilate, to receptors in gland homogenates. Parallel investigations of receptors in exorbital lacrimal glands, an organ that is not grossly affected by chronic isoproterenol treatment, were also carried out. $\left[{ }^{3} \mathrm{H}\right] \mathrm{QNB}$ bound to submandibular receptors with a $K_{\mathrm{d}}$ of $37.8 \pm 6.3 \mathrm{pM}$ in control rats and $41.0 \pm 4.0$ pM in isoproterenol-treated animals, a non-significant difference $(P>0.05)$. In contrast, the maximal binding level $\left(B_{\max }\right)$ in isoproterenol-treated rats, $1.52 \pm 0.10 \mathrm{fmol} / \mu \mathrm{g}$ DNA, was depressed by approx. $30 \%$ $(P<0.05)$ from that of $2.22 \pm 0.16 \mathrm{fmol} / \mu \mathrm{g}$ DNA in control animals. In lacrimal glands, both $K_{\mathrm{d}}(61.3 \pm 5.3$ vs. $53.2 \pm 4.0 \mathrm{pM})$ and $B_{\max }(1.74 \pm 0.24 \mathrm{vs}$. $1.78 \pm 0.17 \mathrm{fmol} / \mu \mathrm{g}$ DNA) were unchanged by isoproterenol treatment. The affinity of glandular muscarinic receptors for cholinergic agonists was also examined by competition experiments using carbachol. This agonist inhibited $\left[{ }^{3} \mathrm{H}\right] \mathrm{QNB}$ binding to receptors in homogenates from both glands in a dose-dependent fashion. Inhibition constants $\left(K_{i}\right)$ for this interaction were similar in control and isoproterenol-treated lacrimal glands; $53.6 \pm 5.4 \mu \mathrm{M}$ and $66.6 \pm 7.9 \mu \mathrm{M}$, respectively $(P>0.05)$. In submandibular glands, isoproterenol treatment elicited a highly significant $(P<0.01)$ shift in $K_{\mathrm{i}}$ from $17.3 \pm 1.4 \mu \mathrm{M}$ to $68.3 \pm 5.2 \mu \mathrm{M}$. These results demonstrate that chronic administration of isoproterenol to rats results in a reduction in receptor numbers and a decrease in their sensitivity to cholinergic agonists in submandibular, but not lacrimal, glands.

\section{Introduction}

Chronic administration of the $\beta$-adrenergic agonist, DL-isoproterenol, to rodents causes a profound enlargement of the parotid and submandibular glands [1-3]. Salivary gland enlargement, which apperas to be mediated via chronic activation of $\beta$-1-adrenergic receptors in the affected

Abbreviation: QNB, L-quinuclidinyl benzilate. organs [4], is brought about by a combination of cellular hyperplasia and hypertrophy [3,5]. Secretory acini are thus more numerous and the individual secretory cells of which they are comprised are larger, with increased granule contents [6]. The functional features of these glands also appear to be altered by chronic isoproterenol treatment. Both qualitative and quantitative differences in the proteins synthesized by submandibular glands have been reported [7]. In addition, both the amounts and species of protein in the secretory effluents 
produced by the parotid [8] and submandibular glands [9] are altered by chronic isoproterenol treatment, and rates of secretory effluent production elicited by either muscarinic cholinergic [10] or $\alpha$-adrenergic [9] secretagogues are reduced. In recent studies on isolated parotid acinar cells from isoproterenol-treated rats, Mangos et al. [11] also have detected abnormalities in cellular morphology and in the ability of these cells to regulate internal cation concentrations and levels of cyclic nucleotides. These studies suggest that abnormalities in the production and composition of parotid and submandibular saliva in the isoproterenoltreated rat arise from profound alterations in cellular metabolism in the secretory parenchyma of the affected organs. One possible alteration, suggested by the low flow rates elicited in isoproterenol-treated glands by cholinomimetics, is a reduction in the numbers of cholinergic receptors in acinar cells or a decrease in the sensitivity of these receptors to activation by acetylcholine and its analogues.

In the studies reported on in the present communication, I have investigated these possibilities by analyzing certain aspects of the binding of the muscarinic cholinergic antagonist, L-quinuclidinyl $\left[{ }^{3} \mathrm{H}\right]$ benzilate (QNB) to receptors in homogenates prepared from submandibular glands of control and chronically isoproterenol-treated rats. Exorbital lacrimal glands also were included in the study as an internal control since, although they contain $\beta$-adrenergic receptors which play a minor role in secretory effluent production [12], they do not undergo enlargement after chronic administration of isoproterenol [2]. The results of these experiments demonstrate that both the average number of muscarinic receptors per cell and the affinity of these receptors for cholinergic agonists are decreased in submandibular glands from rats treated with isoproterenol for 2-3 weeks. No changes in these parameters of $\left[{ }^{3} \mathrm{H}\right] \mathrm{QNB}$ binding were seen in lacrimal glands from the same animals.

\section{Methods}

Animals and treatments. Male Sprague-Dawley rats, 4-5-weeks-old, were purchased from Charles River Breeding Laboratories, Inc. (Wilmington, MA). Upon arrival, rats were divided randomly into control and experimental groups of equal size. Animals in the experimental group received twice daily subcutaneous injections of $0.25 \mathrm{ml}$ of 10 $\mathrm{mg} / \mathrm{ml} \mathrm{DL-isoproterenol} \mathrm{in} 0.9 \%$ saline for $14-21$ days, a protocol which induces substantial enlargement of the salivary glands [11]. Control rats received an identical regimen of saline injections. All animals were allowed free access to water and laboratory chow throughout this period. Rats received final injections in the evening of the day before they were to be used for experimentation and were then fasted until use. All rats were killed between 7 and 9 a.m. on the days of experiments.

Reagents. All chemicals used were of reagent grade quality. Most were obtained from Fisher Scientific Co. (Fair Lawn, NJ) and Sigma Chemical Co. (St. Louis, MO). L-Quinuclidinyl $\left[{ }^{3} \mathrm{H}\right]$ benzilate $(33.1 \mathrm{Ci} / \mathrm{mmol})$ was obtained from New England Nuclear Corp. (Boston, MA).

Tissue preparation. Rats were anesthetized on the mornings of experiments by intraperitoneal injection of $0.25 \mathrm{ml}$ of sodium pentobarbital ( 50 $\mathrm{mg} / \mathrm{ml}$ ) and exsanguinated by transsection of the dorsal abdominal aorta. The paired submandibular and exorbital lacrimal glands were then excised, trimmed of connective tissue and weighed. Glands were homogenized with a motorized Teflon homogenizer in chilled $50 \mathrm{mM}$ sodium phosphate buffer ( $\mathrm{pH} \mathrm{7.4)}$ to a concentration of $10 \mathrm{mg}$ wet wt./ml. Homogenates were filtered once through a single layer of fine nylon mesh and held on ice.

$\left[{ }^{3} \mathrm{H}\right] \mathrm{QNB}$ binding assay. The assay used was modified from that of Yamamura and Snyder [13]. Binding reactions were carried out in $5.0 \mathrm{ml}$ of incubation medium consisting of $50 \mathrm{mM}$ sodium phosphate buffer $(\mathrm{pH} 7.4)$ and varying amounts of $\left[{ }^{3} \mathrm{H}\right] \mathrm{QNB}$, other drugs, and homogenate. Specific binding of $\left[{ }^{3} \mathrm{H}\right] \mathrm{QNB}$ to homogenate receptors was determined as the difference between binding in the absence of atropine (total binding) and in the presence of an excess of this competing muscarinic antagonist (nonspecific binding). To this end, duplicate tubes containing $10 \mu \mathrm{M}$ atropine sulfate in addition to the above were included in each assay.

Binding reactions were initiated by addition of $0.5 \mathrm{ml}$ of homogenate to tubes containing $4.5 \mathrm{ml}$ of temperature-equilibrated incubation medium. All incubations in this study were carried out at 
$37^{\circ} \mathrm{C}$ for $120 \mathrm{~min}$, since preliminary experiments showed that this length of time was adequate for equilibrium binding conditions to be attained at $25 \mathrm{pM}\left[{ }^{3} \mathrm{H}\right] \mathrm{QNB}$, the lowest concentration used. Incubations were terminated by pouring the suspensions over Whatman GF/B glass fiber filters mounted in a vacuum filtering apparatus and rinsing each filter three times with $5.0 \mathrm{ml}$ aliquots of ice-cold incubation buffer. Rinsed filters were placed directly in scintillation vials and extracted in a 1:10 mixture of Protosol and Omnifluor (New England Nuclear). Vials were then counted in a Beckman LS-9000 liquid scintillation spectrometer.

DNA and protein assay. Protein in gland homogenates was estimated by the method of Peterson [14], using bovine serum albumin as a standard. DNA was estimated, using calf thymus DNA, by the diphenylamine procedure of Croft and Lubran [15].

\section{Results}

\section{Adaptive response to isoproterenol treatment}

Rats were killed at approx. 50 days of age, after $2-3$ weeks of isoproterenol or saline injections. The average weight of isoproterenol-treated rats at the time of death was $199 \pm 10 \mathrm{~g}$. Control animals were somewhat heavier at $238 \pm 24 \mathrm{~g}$. All isoproterenol-treated rats survived the drug regimen with few noticeable ill effects other than this small depression in weight gain. Conspicuous enlargement of the salivary glands was readily seen after the first few days of treatment in even a cursory external examination of the animals. This enlarge- ment is illustrated by the data in Table I. Submandibular glands in isoproterenol-treated rats were 3-4-fold heavier than their counterparts in control animals. Glandular protein content was roughly four times as great, while DNA was increased 2-fold. These data show that the isoproterenol-induced enlargement of submandibular glands is the product of two separate processes, hyperplasia within the glandular parenchyma and hypertrophy of individual secretory cells, findings which confirm those of earlier studies $[3,5,10]$. No differences were noted in gland weights, protein, or DNA when lacrimal glands from control and isoproterenol-treated rats were compared.

\section{Characterization of $\left[{ }^{3} \mathrm{H}\right] Q N B$ binding}

Specific binding of $\left[{ }^{3} \mathrm{H}\right] \mathrm{QNB}$ to receptors in homogenates of both glands was saturable, as shown in Figs. 1 and 2. Nonspecific binding, in contrast, was lineraly dependent on concentration of $\left[{ }^{3} \mathrm{H}\right] \mathrm{QNB}$ over the range studied, $25-800 \mathrm{pM}$, but did not constitute a major portion of total binding at even the highest concentration. The specific saturation binding isotherms for both glands in both experimental conditions generated Scatchard plots consisting of single straightlines with correlation coefficients between 0.90 and 1.00 (Fig. 3). These data indicate that the muscarinic receptor in both glands behaves as an homogenous class of binding sites with respect to its interaction with the tritiated antagonist. Equilibrium dissociation constants $\left(K_{\mathrm{d}}\right)$ and maximal binding levels $\left(B_{\max }\right)$ were determined from these plots and are shown in Table II. $K_{\mathrm{d}}$ for the $\left[{ }^{3} \mathrm{H}\right] \mathrm{QNB}$-receptor interaction was not altered in either the lacrimal or

TABLE I

EFFECT OF DL-ISOPROTERENOL ON RAT LACRIMAL AND SUBMANDIBULAR GLANDS

Male Sprague-Dawley rats were injected with approx. $25 \mathrm{mg}$ isoproterenol/kg body weight for 14-21 days. Values represent the means \pm S.E. of determinations from the glands of five animals in each group.

\begin{tabular}{lccc}
\hline Gland & $\begin{array}{l}\text { Wet weight } \\
(\mathrm{mg})\end{array}$ & $\begin{array}{l}\text { Protein } \\
(\mathrm{mg})\end{array}$ & $\begin{array}{l}\text { DNA } \\
(\mathrm{mg})\end{array}$ \\
\hline Lacrimal (control) & $77.2 \pm 9.5$ & $9.83 \pm 2.15$ & $0.253 \pm 0.035$ \\
Lacrimal (isoproterenol) & $63.9 \pm 7.8$ & $8.25 \pm 1.06$ & $0.269 \pm 0.037$ \\
Submandibular (control) & $256 \pm 17$ & $30.8 \pm 3.9$ & $1.14 \pm 0.07$ \\
Submandibular (isoproterenol) & $824 \pm 67^{\mathrm{a}}$ & $126.7 \pm 13.6^{\mathrm{a}}$ & $2.22 \pm 0.11^{\mathrm{a}}$ \\
\hline
\end{tabular}

a Significant difference $(P<0.05)$ determined by Student's $t$-test. 


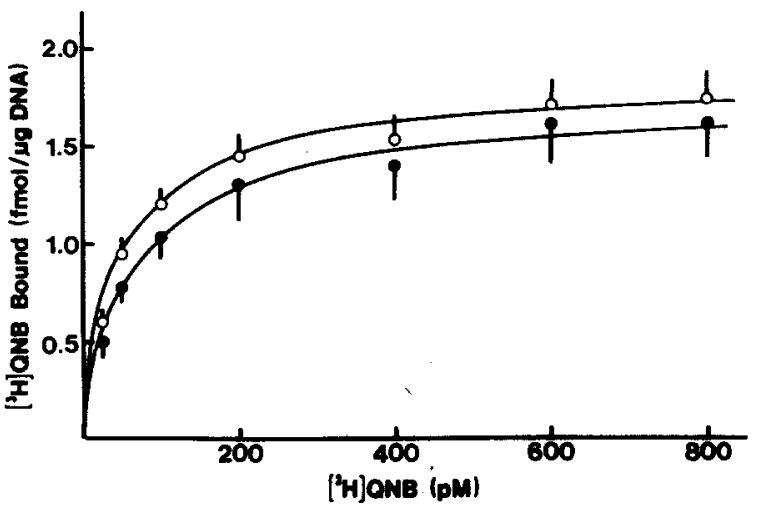

Fig. 1. Specific binding of $\left[{ }^{3} \mathrm{H}\right] \mathrm{QNB}$ to exorbital lacrimal gland homogenate receptors from control $(O)$ and isoproterenoltreated $(O)$ glands as a function of medium $\left[{ }^{3} \mathrm{H}\right] \mathrm{QNB}$ concentration. Data points represent the means \pm S.E. of five experiments for each condition. Incubations were carried out for $120 \mathrm{~min}$ at $37^{\circ} \mathrm{C}$ as detailed in the text.

submandibular glands by chronic isoproterenol treatment. The $K_{\mathrm{d}}$ in lacrimal glands was somewhat higher than that in submandibular glands, possibly a reflection of the differing plasma membrane microenvironments in these two organs. Isoproterenol treatment did not alter the maximal binding level for $\left[{ }^{3} \mathrm{H}\right] \mathrm{QNB}$ in lacrimal glands, either on the basis of protein, DNA, or total gland content. In submandibular glands, however, administration of the $\beta$-adrenergic agonist caused a

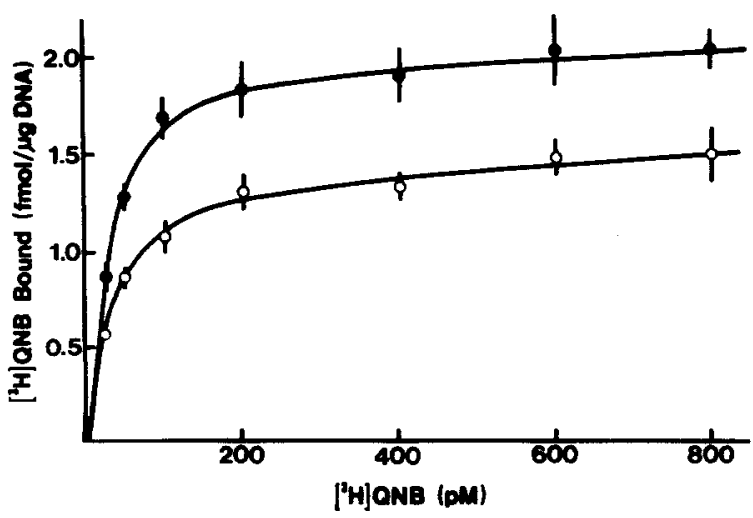

Fig. 2. Specific $\left[{ }^{3} \mathrm{H}\right] \mathrm{QNB}$ binding to receptors in homogenates of submandibular glands from control $(\ominus)$ and isoproterenoltreated (O) rats expressed as a function of $\left[{ }^{3} \mathrm{H}\right] \mathrm{QNB}$ concentration. Incubation time was $120 \mathrm{~min}$ at $37^{\circ} \mathrm{C}$. Five experiments. significant $(P<0.05)$ depression in $\left[{ }^{3} \mathrm{H}\right] \mathrm{QNB}$ binding, expressed relative to either protein or DNA. While this decrease is most striking when expressed relative to the former (89.4 vs. 27.3 $\mathrm{fmol} / \mathrm{mg}$ protein), relating specifically bound $\left[{ }^{3} \mathrm{H}\right] \mathrm{QNB}$ to DNA more accurately reflects the change in numbers of muscarinic receptors per cell. When expressed in this fashion, the decrease assumes more modest proportions, 2.22 to 1.52 $\mathrm{fmol} / \mu \mathrm{g}$ DNA. This reduction in binding is significant at the 0.05 level. Although average cellular receptor populations are depressed in submandibular glands of isoproterenol-treated rats, the total glandular muscarinic receptor complement is increased somewhat. This increase most probably can be attributed to newly synthesized receptors in the acinar cells recruited during the hyperplastic phase of gland enlargement.

The possibility that chronic isoproterenol treatment might alter the affinity for cholinergic agonists of muscarinic receptors in the two glands was also explored. Carbachol was added at concentrations from $5 \mu \mathrm{M}$ to $10 \mathrm{mM}$ to incubation media containing $100 \mathrm{pM}\left[{ }^{3} \mathrm{H}\right] \mathrm{QNB}$ and the resulting competition curves were plotted as shown in Fig. 4. The curves for control and isoproterenol-treated lacrimal glands overlapped. Hill coefficients for these competition curves were 0.795 and 0.808 , respectively. Inhibition constants $\left(K_{\mathrm{i}}\right)$, calculated as in Fields et al. [16], were also very similar; $53.6 \pm 5.4 \mu \mathrm{M}$ in controls and $66.6 \pm$ $7.9 \mu \mathrm{M}$ in isoproterenol-treated glands $(P>0.05)$. These data indicate that chronic administration of

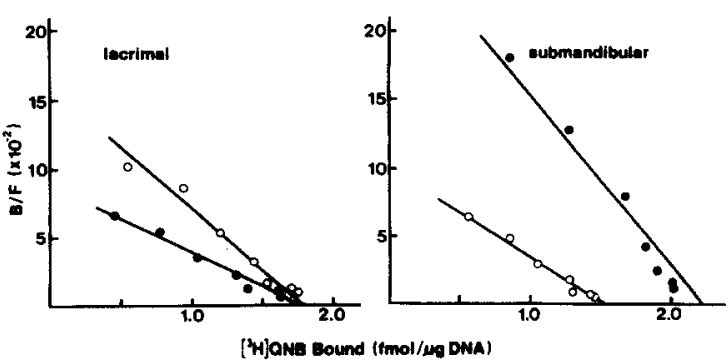

Fig. 3. Scatchard analyses of saturation binding isotherms from Figs. 1 and 2. Correlation coefficients $(r)$ for control $(O)$ and isoproterenol-treated $(O)$ lacrimal glands were 0.975 and 0.963 , respectively. Corresponding values for submandibular glands were 0.897 and 0.972 . 
TABLE II

EFFECT OF DL-ISOPROTERENOL ON $\left[{ }^{3} \mathrm{H}\right] \mathrm{QNB}$ BINDING TO RAT LACRIMAL AND SUBMANDIBULAR GLAND MUSCARINIC ACETYLCHOLINE RECEPTORS

Values represent the means \pm S.E. of determinations from the glands of five animals in each group.

\begin{tabular}{|c|c|c|c|c|}
\hline \multirow[t]{2}{*}{ Gland } & \multirow{2}{*}{$\begin{array}{l}K_{\mathrm{d}} \\
(\mathrm{pM})\end{array}$} & \multicolumn{3}{|l|}{$B_{\max }$} \\
\hline & & $\mathrm{fmol} / \mathrm{mg}$ protein & $\mathrm{fmol} / \mu \mathrm{g}$ DNA & $\mathrm{pmol} /$ gland \\
\hline Lacrimal (control) & $61.3 \pm 5.3$ & $47.4 \pm 6.5$ & $1.74 \pm 0.24$ & $0.455 \pm 0.098$ \\
\hline Lacrimal (isoproterenol) & $53.2 \pm 4.0$ & $58.3 \pm 5.3$ & $1.78 \pm 0.17$ & $0.467 \pm 0.051$ \\
\hline Submandibular (control) & $37.8 \pm 6.3$ & $89.4 \pm 15.7$ & $2.22 \pm 0.16$ & $2.53 \pm 0.24$ \\
\hline Submandibular (isoproterenol) & $41.0 \pm 4.0$ & $27.3 \pm 2.6^{a}$ & $1.52 \pm 0.10^{\mathrm{a}}$ & $3.38 \pm 0.29^{a}$ \\
\hline
\end{tabular}

a Significant difference at 0.05 level, determined by Student's $t$-test.

isoproterenol to rats has little, if any, effects on the functional properties of muscarinic acetylcholine receptors in exorbital lacrimal glands. In contrast, isoproterenol treatment caused a substantial shift in the carbachol competition curve with submandibular gland homogenates (Fig. 4). The calculated $K_{\mathrm{i}}$ for control glands was $17.3 \pm 1.4$ $\mu \mathrm{M}$, while that for isoproterenol-treated glands was $68.3 \pm 5.2 \mu \mathrm{M}$, a highly significant difference $(P<0.01)$. Hill coefficients were 0.628 and 0.676 , respectively. These results suggest a shift toward lessened sensitivity to agonists in muscarinic receptors of submandibular glands in chronically isoproterenol-treated animals.

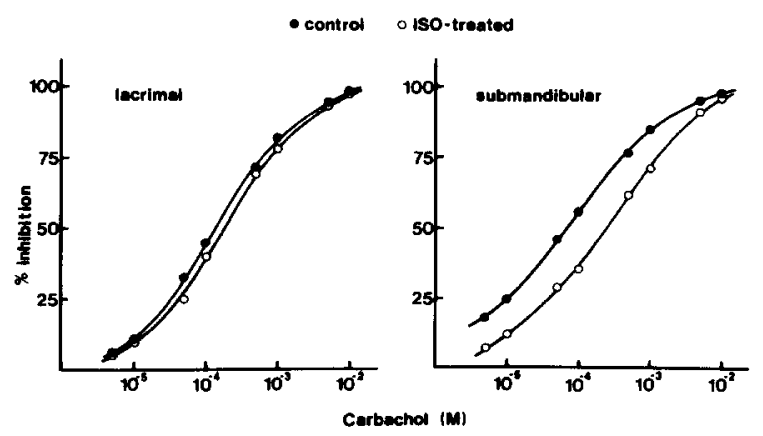

Fig. 4. Inhibition of specific $\left[{ }^{3} \mathrm{H}\right] \mathrm{QNB}$ binding to receptors in homogenates of rat lacrimal and submandibular glands from control $(\Theta)$ and isoproterenol-treated $(O)$ animals by carbachol. Medium $\left[{ }^{3} \mathrm{H}\right] \mathrm{QNB}$ concentration was $100 \mathrm{pM}$ and incubations were carried out at $37^{\circ} \mathrm{C}$ for $120 \mathrm{~min}$. Each curve represents the average of three experiments. Standard errors of means were less than $10 \%$ at most data points.

\section{Discussion}

The evidence presented in this paper suggests that chronic treatment of rats with DL-isoproterenol, a $\beta$-adrenergic agonist, elicits significant qualitative and quantitative differences in the muscarinic cholinergic receptors of submandibular glands. Receptor properties in exorbital lacrimal glands from the same animals, however, remain unaffected by the drug treatment.

Parameters of binding of the muscarinic cholinergic antagonist, $\left[{ }^{3} \mathrm{H}\right] \mathrm{QNB}$, to receptors in homogenates from both glands are similar to those in other previously examined exocrine organs, including the rat parotid gland [17] and the duck salt gland [18]. $\left[{ }^{3} \mathrm{H}\right] \mathrm{QNB}$ binding is saturable, with a calculated $K_{\mathrm{d}}$ of less than $100 \mathrm{pM}$. Binding is also competitively inhibited by other muscarinic ligands, both antagonists (atropine) and agonists (carbachol). Maximal binding levels expressed a fmol $\left[{ }^{3} \mathrm{H}\right] \mathrm{QNB} / \mu \mathrm{g}$ DNA can be converted to average numbers of receptors per cell, since somatic mammalian cells characteristically contain about 6 pg DNA [19]. These conversions give receptor numbers of $6290 /$ cell in control lacrimal glands and 8020 /cell in submandibular glands from control rats. These values are in good agreement with those of 4900 and 23000 calculated for rat parietal cells [20] and parotid acinar cells [21], respectively. It is worth noting here that the present values represent averages across the glands and thus include not only secretory acinar cells but cells in 
glandular excretory ducts as well as those in connective tissue and vascular compartments. It is thus not possible at present to accurately quantitate muscarinic receptor populations in specific intraglandular cell types, an endeavor that would require the application of autoradiographic and/or tissue dispersion and cell separation techniques.

In the submandibular glands, a decrease in cellular muscarinic receptors of approx. 30\% was observed following 2-3 weeks of chronic isoproterenol administration. Although this represents a significant depression in the calculated average number of receptors per cell $(8020-5490)$, it is again not possible to say with certainty whether this represents a moderate generalized reduction or a more dramatic decrease in a particular cell type. Indirect evidence, however, suggests that acinar cells in particular may be those most affected. Studies with dispersed rat submandibular acini have demonstrated their responsiveness to both muscarinic cholinergic and $\beta$-adrenergic stimuli [22-24]. In addition, the hypertrophic and hyperplastic responses seen in submandibular glands to chronic isoproterenol administration primarily involve secretory acini. Striated and granular duct cells are not markedly enlarged [10]. It thus is reasonable to assume that the reduction in muscarinic receptors observed represents a reduction in the receptor complement of acinar cells, a decrease that may actually exceed the average reduction measured.

The other significant alteration in submandibular muscarinic acetylcholine receptors induced by chronic isoproterenol treatment was a decrease in the affinity of the receptor for carbachol. The competition binding curves for this agonist from both control and isoproterenol-treated glands give Hill coefficients that are lower than expected from a simple mass action competition. Birdsall et al. [25], Schimerlik and Searles [26] and others have recently demonstrated that this discrepancy can be explained if muscarinic receptors contain two binding sites with identical affinities for antagonists but which differ in their affinities for agonists. Thus, muscarinic receptors in the submandibular gland appear to be homogenous with respect to their affinity for antagonists (Fig. 3) and heterogenous with respect to agonist affinities (Fig.4). Chronic isoproterenol administration de- creased the ability of carbachol to inhibit $\left[{ }^{3} \mathrm{H}\right] \mathrm{QNB}$ binding to submandibular gland homogenates by approx. 4-fold, as judged by the shift in $K_{\mathrm{i}}$ from 17.3 to $68.3 \mu \mathrm{M}$. Accompanying this alteration in binding affinity was a small increase in the Hill coefficient from 0.63 to 0.68 . These data are strikingly similar to those obtained in embryonic chick heart [27], where in ovo treatment with carbachol decreased the $\mathrm{IC}_{50}$ for carbachol inhibition of $\left[{ }^{3} \mathrm{H}\right] \mathrm{QNB}$ binding from 8 to $32 \mu \mathrm{M}$ (4-fold) and increased the Hill coefficient from 0.52 to 0.65 . In this study, the increase in Hill coefficient was clearly shown to result from a decrease in the heterogeny of the receptor population brought about by a preferential reduction in the proportion of high affinity agonist binding sites, an alteration that decreases the average affinity of the receptor population for agonists as well. The close correspondence of data obtained in the present study suggests that similar alterations may take place in the muscarinic receptor population of submandibular glands from rats undergoing chronic isoproterenol treatment.

Reduction of muscarinic receptors by chronic receptor activation has been observed in a number of biological systems, including embryonic chick heart [27], cultured neuroblastoma cells [28], and intact rat brain [29] and pancreas [30]. The fact that depression of muscarinic receptors in secretory epithelia can also be elicited by chronic $\beta$ adrenergic stimulation appears to be a novel observation. Little is known about the way in which $\beta$-adrenergic and muscarinic cholinergic stimulusresponse coupling systems in epithelia feedback on each other at the subcellular level, although Burke and Barka [31] recently demonstrated that chronic isoproterenol treatment increases cyclic AMP levels in intact salivary glands. This finding is confirmed by the studies of Mangos et al. [11] on dispersed parotid acinar cells. In this latter study, a reciprocal decrease in intracellular cyclic GMP levels was also observed. Whether these changes are directly involved in modulation of muscarinic acetylcholine receptor numbers and sensitivity to agonists remains to be elucidated. The profound stimulatory effects of isoproterenol administration on DNA and protein synthesis in the submandibular gland raise the possibility that muscarinic receptor synthesis might be affected at the transcriptional or translational level. 
An interesting feature in the present study was the complete absence of effects of isoproterenol administration on the exorbital lacrimal glands. Acinar cells in these glands contain $\beta$-adrenergic receptors [12] although, in contrast to submandibular glands, they apparently play only a minor role in secretory effluent production. Why isoproterenol administration does not induce cell division or hypertrophy, or alter the properties of muscarinic receptors, therefore must not be the absence of receptors for the agonist. More subtle features of receptor-effector coupling are likely involved.

The decrease seen in muscarinic receptors and in their agonist sensitivity in submandibular glands of isoproterenol-treated rats may have important functional significance with respect to secretory effluent production. When compared with control animals, salivary production by treated glands shows substantial differences. Protein concentration in saliva is elevated while the flow rate is markedly reduced $[9,10]$. In addition, there are qualitative differences in the species of proteins secreted [9]. The difference in flow rate could clearly result from a decreased cholinergic responsiveness without there being marked changes in the ionic composition of the primary effluent produced by secretory acini. The combination of low flow rates and increased protein concentration in submandibular saliva may increase the viscosity of the secreted fluid and thus predispose the treated animals to glandular excretory duct obstructions and pathologic infections. Isoproterenol-treated rats, for instance, have a greater incidence of dental caries than control animals [32]. Interestingly, pathological symptoms of this nature have also been reported in patients with cystic fibrosis, a disease for which the chronically isoproterenolized rat has been suggested as an animal model [11]. It will be of great interest in the future to determine whether fundamental alterations in muscarinic receptors in the salivary glands of affected individuals contribute to the exocrinopathy of this disease as they appear to contribute to abnormal submandibular gland function in the isoproterenoltreated rat.

\section{Acknowledgements}

The author thanks Dr. Stephen A. Ernst for his helpful discussions and careful reading of this manuscript. This research was supported by USPHS grant AM 27559.

\section{References}

1 Brown-Grant, K. (1961) Nature 191, 1076-1078

2 Selye, H., Veilleux, R. and Cantin, M. (1961) Science 133, 44-45

3 Novi, A.M. and Baserga, R. (1971) Am. J. Pathol. 62, 295-308

4 Brenner, G.M. and Wulf, R.G. (1981) J. Pharmacol. Exp. Ther. 218, 608-612

5 Barka, T. and Van der Noen, H. (1976) Lab. Invest. 35, 507-514

6 Bressler, R.S. (1973) Am. J. Anat. 138, 431-447

7 Denny, P.C. and Denny, P.A. (1981) Arch. Oral Biol. 26, 297-301

8 Robinovitch, M.R., Keller, P.J., Johnson, D.A., Iverson, J.M. and Kauffman, D.L. (1977) J. Dent. Res. 56, 290-303

9 Abe, K. and Dawes, C. (1980) J. Dent. Res. 59, 1081-1089

10 Schneyer, C.A. (1962) Am. J. Physiol. 203, 232-236

11 Mangos, J.A., Boyd, R.L., Bouchlas, D. and Farnham, W. (1981) J. Dent. Res. 60, 80-85

12 Friedman, Z.Y., Lowe, M. and Selinger, Z. (1981) Biochim. Biophys. Acta 675, 40-45

13 Yamamura, H.I. and Snyder, S.H. (1974) Proc. Natl. Acad. Sci. U.S.A. 71, 1725-1729

14 Peterson, G.L. (1977) Anal. Biochem. 83, 346-356

15 Croft, D.N. and Lubran, M. (1965) Biochem. J. 95, 612-620

16 Fields, J.Z., Roeske, W.R., Morkin, E. and Yamamura, H.I. (1978) J. Biol. Chem. 253, 3251-3258

17 Ludford, J.M. and Talamo, B.R. (1980) J. Biol. Chem. 255, 4619-4627

18 Hootman, S.R. and Ernst, S.A. (1981) J. Cell Biol. 91, 781-789

19 Lehninger, A.L. (1975) Biochemistry, 2nd ed., Worth Publishers, Inc., New York

20 Ecknauer, R., Thompson, W.J., Johnson, L.R. and Rosenfeld, G.C. (1980) Am. J. Physiol. 239, G204-G209

21 Putney, J.W., Jr. and Van De Walle, C.M. (1980) J. Physiol. 299, 521-531

22 Quissell, D.O. and Redman, R.S. (1979) Proc. Natl. Acad. Sci. U.S.A. 76, 2789-2793

23 Quissell, D.O. (1980) Am. J. Physiol. 238, C90-C98

24 Quissell, D.O.and Barzen, K.A. (1980) Am. J. Physiol. 238, C99-C106

25 Birdsall, N.J.M., Burgen, A.S.V. and Hulme, E.C. (1978) Mol. Pharmacol. 17, 723-736

26 Schimerlik, M.I. and Searles, R.P. (1980) Biochemistry 19, 3407-3413

27 Halvorsen, S.W. and Nathanson, N.M. (1981) J. Biol. Chem. $256,7941-7948$

28 Shifrin, G.S. and Klein, W.L. (1980) J. Neurochem. 34, 993-999

29 Schiller, G.D. (1979) Life Sci. 24, 1159-1164

30 Larose, L., Dumont, Y., Poirier, G.G. and Morisset, J. (1981) Fed. Proc. 40, 710

31 Burke, G.T. and Barka, T. (1978) Biochim. Biophys. Acta $539,54-61$

32 Menaker, L. and Navia, J.M. (1975) Caries Res. 9, 83-90 